\title{
Endovascular acute ischemic stroke therapy
}

\author{
Society of Vascular and Interventional Neurology \\ roundtable proceedings
}

Osama O. Zaidat, MD, MS

Dileep R. Yavagal, MD

Correspondence \& reprint requests to Dr. Zaidat: szaidat@mcw.edu

Neurology ${ }^{\circledR}$ 2012;79 (Suppl 1):S1-S2
Over 15 years ago, the US Food and Drug Administration (FDA) approved the use of tissue plasminogen activator ( $\mathrm{tPA}$ ) for acute ischemic stroke (AIS) within 3 hours of symptom onset. ${ }^{1}$ Since then, additional landmark advancements in AIS included the results of the Prolyse in Acute Cerebral Thromboembolism (PROACT) trial and the Middle Cerebral Artery Embolism Local Fibrinolytic Intervention Trial (MELT), which showed improved clinical outcome following local intra-arterial therapy, in comparison with placebo, and expanded the therapeutic treatment window of AIS. ${ }^{2,3}$ Because of the limited rate of recanalization by systemic and local chemical thrombolysis, mechanical thrombectomy became the next area of interest with the hope of achieving safer and faster recanalization. In the past decade, 4 major prospective studies of single-arm devices have yielded high rates of recanalization and FDA approval of 2 devices for thrombectomy. ${ }^{4-8}$ To take advantage of both early treatment initiation with systemic thrombolysis and the high rate of recanalization with endovascular therapy, the Interventional Management of Stroke (IMS) II feasibility trial evaluated the safety and potential clinical efficacy of this bridging approach. ${ }^{9}$ The results of IMS II set into motion IMS III, the largest randomized endovascular AIS trial to evaluate the efficacy of a combined intravenous and intra-arterial approach for the treatment of AIS. Although IMS III was halted due to preplanned interim analysis showing the very low likelihood of demonstrating a significant difference between the 2 treatment arms, data from IMS III may serve as a foundation for future endovascular AIS trials.

Despite advancements in AIS therapy, complex questions and considerable challenges remain for endovascular treatment. Patient selection is a critical element in achieving success and efficacy with endovascular therapy; however, our current understanding of the factors influencing patient selection is limited. Enthusiasm for imaging-based triage has prompted extensive investigation of this alternative approach to the conventional time-based model and may lead to improved patient selection. Advancements in device design are rapidly evolving the next generation of technology for thrombectomy, which will demand rigorous appraisal of safety and efficacy. Institutional requirements and operator training are important elements that will need further definition, although considerable effort has already led to specific published recommendations to standardize endovascular stroke therapy performance training criteria and credentialing, as well as criteria for comprehensive stroke centers. ${ }^{10,11}$

To review the current status of AIS knowledge, including the latest scientific evidence, important gaps in the current state of knowledge, common ground for practice standards, and the future direction of AIS endovascular therapy, the Society of Vascular \& Interventional Neurology (SVIN) planned and funded a roundtable conference, held July $24-25$, 2008, in Chicago, Illinois. In addition to vascular, critical care, and interventional neurologists, the group included 5 vascular neurologists and 2 neuro-intensivists, the majority of whom attended in person.

The moderated sessions were divided among these categories:

I. Epidemiology and public health perspective on AIS endovascular therapy.

II. Pathophysiologic basis of AIS endovascular therapy.

III. Imaging in patient selection for endovascular therapy.

IV. Therapeutics.

V. Periprocedural management.

VI. Future directions in endovascular management of AIS.

Time was dedicated at the end of each session for discussion. The question and answer session began with submission of polling questions relevant to the material presented. Results and relevant polling data are published in this supplement to introduce readers to the controversial questions and polling results. A total of 27 presentations were given by attendees of the roundtable meeting, and manuscripts were subsequently submitted and reviewed by the editors of the supplement. For topics not covered by the roundta-

From the Departments of Neurology, Neurosurgery, and Radiology (O.O.Z.), Medical College of Wisconsin, Madison; and Departments of Neurology and Neurosurgery (D.R.Y.), University of Miami, Miami, FL.

Go to Neurology.org for full disclosures. Disclosures deemed relevant by the authors, if any, are provided at the end of this article. 
ble meeting presentations, invited reviews were written by experts in the field.

This endovascular AIS supplement provides a comprehensive overview of all aspects of stroke clinical care and current knowledge. This information is of importance in providing treatment and research guidance to practicing clinicians, basic scientists, clinical researchers, public health policy makers, and medical device and drug manufacturers.

\section{AUTHOR CONTRIBUTIONS}

Drs. Zaidat and Yavagal participated in the design, writing, and editing of the final version of the manuscript.

\section{ACKNOWLEDGMENT}

For their help in making this Endovascular AIS Therapy supplement possible, the authors owe special thanks to the roundtable presenters and manuscript authors; Maria Wellenstein, NP, and Alicia Castonguay, $\mathrm{PhD}$, for editorial assistance; and Junaid S. Kalia, MD, for help with collating the manuscripts. In addition, the authors thank the Neurology ${ }^{\circledR}$ Stroke Section Associate Editor, Dr. Bradford B. Worrall; Editor-inChief, Dr. Robert A. Gross; Editorial Office staff members Morgan S. Sorenson, Lee Ann Kleffman, Kathleen Pieper, and Cindy Abair; and Lippincott Williams \& Wilkins Wolters Kluwer Health Publisher Kim Jansen and Production Editor Alexandra Lazerow.

\section{DISCLOSURE}

Dr. Zaidat serves on the scientific advisory board for Talecris; served on the adjudication committee for Stryker MAPS trial; received speaker honoraria from Stryker; serves on the editorial board of Frontiers in Neurology (Endovascular \& Interventional Neurology Section); serves as an Associate Editor of the Journal of Neurointerventional Surgery and serves on the Editorial Board of Journal of Stroke \& Cerebrovascular Diseases; served as a consultant for Stryker Neurovascular-Commercial, Codman Neurovascular-Commercial, Microvention Inc, Commercial; and has received research support from a Society of Vascular \& Interventional Neurology (SVIN) grant for this educational activity. Dr. Yavagal received an honorarium from Penumbra Inc. for consultation and speaking; serves as an Associate Editor for Frontiers in Endovascular Neurology; and serves as a consultant to Penumbra Inc., Codman Neurovascular, Micrus Inc., Genentech, and Boston Scientific. Go to Neurology.org for full disclosures.

Received June 27, 2011. Accepted in final form February 29, 2012.

\section{REFERENCES}

1. NINDS Study Group. Tissue plasminogen activator for acute ischemic stroke. N Engl J Med 1995;333:15811587.
2. Furlan A, Higashida R, Wechsler L, et al. Intra-arterial prourokinase for acute ischemic stroke. The PROACT II study: a randomized controlled trial. JAMA 1999;282: 2003-2011.

3. Ogawa A, Mori E, Minematsu K, et al. Randomized trial of intra-arterial infusion of urokinase within 6 hours of middle cerebral artery stroke: the middle cerebral artery embolism local fibrinolytic intervention trial (MELT). Stroke 2007;38:2633-2639.

4. Smith WS, Sung G, Saver J, et al. Mechanical thrombectomy for acute ischemic stroke: final results of the Multi MERCI trial. Stroke 2008;39:1205.

5. Gobin YP, Starkman S, Duckwiler GR, et al. MERCI 1: a phase 1 study of mechanical embolus removal in cerebral ischemia. Stroke 2004;35:2848-2853.

6. Starkman S. Results of the combined MERCI I-II (Mechanical Embolus Removal in Cerebral Ischemia) trials. Stroke 2004;35:240.

7. Bose A, Henkes H, Alfke K, et al. The Penumbra System: a mechanical device for the treatment of acute stroke due to thromboembolism. Am J Neuroradiol 2008;29:1409.

8. Penumbra Pivotal Stroke Trial Investigators. The penumbra pivotal stroke trial: safety and effectiveness of a new generation of mechanical devices for clot removal in intracranial large vessel occlusive disease. Stroke 2009; 40 : 2761-2768

9. IMS II Trial Investigators. The Interventional Management of Stroke (IMS) II Study. Stroke 2007;38:21272135.

10. Meyers PM, Schumacher HC, Alexander MJ, et al. Performance and training standards for endovascular ischemic stroke treatment: Writing Group for American Academy of Neurology, American Association of Neurological Surgeons Cerebrovascular Section, Society of Neurointerventional Surgery, and Society of Vascular and Interventional Neurology. J Stroke Cerebrovasc Dis 2009;18:411-415.

11. Leifer D, Bravata DM, Connors JJ 3rd, et al; American Heart Association Special Writing Group of the Stroke Council; Atherosclerotic Peripheral Vascular Disease Working Group; Council on Cardiovascular Surgery and Anesthesia; Council on Cardiovascular Nursing. Metrics for measuring quality of care in comprehensive stroke centers: detailed follow-up to Brain Attack Coalition comprehensive stroke center recommendations: a statement for healthcare professionals from the American Heart Association/American Stroke Association [erratum 2011;42: e369]. Stroke 2011;42:849-877. 


\section{Neurology}

\section{Endovascular acute ischemic stroke therapy: Society of Vascular and Interventional Neurology roundtable proceedings \\ Osama O. Zaidat and Dileep R. Yavagal \\ Neurology 2012;79;S1-S2 \\ DOI 10.1212/WNL.0b013e31826957a0}

This information is current as of September 24, 2012

\section{Updated Information \&} Services

References

Subspecialty Collections

Permissions \& Licensing

Reprints including high resolution figures, can be found at: http://n.neurology.org/content/79/13_Supplement_1/S1.full

This article cites 11 articles, 7 of which you can access for free at: http://n.neurology.org/content/79/13_Supplement_1/S1.full\#ref-list-1

This article, along with others on similar topics, appears in the following collection(s):

\section{All Cerebrovascular disease/Stroke}

http://n.neurology.org/cgi/collection/all_cerebrovascular_disease_strok e

\section{Childhood stroke}

http://n.neurology.org/cgi/collection/childhood_stroke

\section{Embolism}

http://n.neurology.org/cgi/collection/embolism

Infarction

http://n.neurology.org/cgi/collection/infarction

Information about reproducing this article in parts (figures,tables) or in its entirety can be found online at:

http://www.neurology.org/about/about_the_journal\#permissions

Information about ordering reprints can be found online:

http://n.neurology.org/subscribers/advertise

Neurology ${ }^{\circledR}$ is the official journal of the American Academy of Neurology. Published continuously since 1951, it is now a weekly with 48 issues per year. Copyright Copyright (? 2012 by AAN Enterprises, Inc.. All rights reserved. Print ISSN: 0028-3878. Online ISSN: 1526-632X.

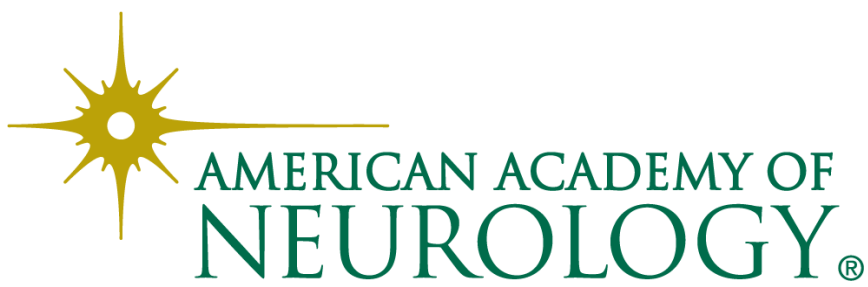

